\title{
An Investigation of the Relationship between Prospective Classroom Teachers' Critical Thinking Standards and Their Attitudes Towards Democracy
}

\author{
Birsel AYBEK ${ }^{\mathrm{a}}$, Serkan ASLAN ${ }^{\mathbf{b}^{*}}$ \\ ${ }^{a}$ Çukurova Üniversitesi, Eğitim Bilimleri Bölümü, Adana/Türkiye \\ ${ }^{b}$ Milli Eğitim Bakanlığı, Nuri Özaltın İlkokulu, Elazığ/Türkiye
}

\section{Article Info}

DOI: 10.14812/cufej.296276

Keywords:

Democratic attitudes, critical thinking standards, attitude, prospective classroom teachers.

\begin{abstract}
The main objective of this study is to analyze the relation between prospective classroom teachers' critical thinking standards and their attitudes towards democracy. The research was carried out with prospective teachers who are from the $1^{\text {st }}, 2^{\text {nd }}, 3^{\text {rd }}$ and $4^{\text {th }}$ grades and who study at the Department of Elementary Teaching at Çukurova University. The study used random sampling method. The research group holds a total of 326 prospective teachers. The study deployed two data collection tools. "Attitude Scale for Democracy" devoloped by Oral (2008) and "Critical Thinking Standards Scale" devoloped by Aybek, Aslan, Dinçer and Coşkun-Arısoy (2015). Pearson productmoment correlation and multivariate variance analysis were used during the data analysis. Research results have demonstrated a positive and medium level of significant relationship between prospective teachers' critical thinking standards and their attitudes towards democracy. The dimensions of critical thinking standards such as depth-breadth-sufficiency, precision-accuracy and significance-relevance-clarity dimensions were found to have a significant relationship with the attitude towards democracy and three variables account for about $38 \%$ of the attitude towards democracy. Proposals were developed based on the findings derived from the research.
\end{abstract}

\section{Sınıf Öğretmeni Adaylarının Eleştirel Düşünme Standartları ile Demokrasiye Yönelik Tutumları Arasındaki îlişkinin İncelenmesi}

Makale Bilgisi

DOI: $10.14812 /$ cufej.296276

Anahtar Kelimeler:

Demokratik tutumlar, eleştirel düşünme standartları, tutum, sınıf öğretmeni adayları

\section{Öz}

Bu çalışmanın amacı, sınıf öğretmeni adaylarının eleştirel düşünme standartları ile demokrasiye yönelik tutumları arasındaki ilişkiyi incelemektir. Araştırmanın evrenini Çukurova Üniversitesi'nde eğitim fakültesinde öğrenim gören $1,2,3$ ve 4 . sınıf öğretmeni adayları oluşturmaktadır. Araştırmada rassal örnekleme yöntemi kullanılmıştır. Araştırmaya 326 öğretmen adayı katılmıştır. Araştırmada veri toplama aracı olarak; Oral (2008) tarafından geliştirilen "Demokrasiye Yönelik Tutum" ölçeği ile Aybek, Aslan, Dinçer ve Coşkun-Arısoy (2015) tarafından geliştirilmiş olan "Eleştirel Düşünme Standartları" ölçeği kullanıımıştır. Verilerin analizinde Pearson Çarpım Momentler Korelasyon analizi ve çoklu doğrusal regresyon analizi kullanılmıştır. Araştırma sonucunda öğretmen adaylarının; eleştirel düşünme standartları puanları ile demokrasiye yönelik tutum puanları arasında pozitif yönlü orta düzeyde anlamlı bir ilişkinin olduğu; eleştirel düşünme standartları ölçeğine ait derinlik-genişlik-yeterlilik, kesinlik-doğruluk ve önem-alaka-açıklık alt boyutlarının demokrasiye yönelik tutum ile anlamlı bir iliş̧i sergilediği ve söz konusu üç değişken birlikte, demokrasiye yönelik tutumun \%38'ini açıkladığı tespit edilmiştir. Araştırma bulgularına dayalı olarak bazı öneriler geliştirilmiştir.

\footnotetext{
* Author: aslan.s1985@gmail.com
} 
Aybek ve Aslan - Çukurova Üniversitesi Eğitim Fakültesi Dergisi, 46(2), 2017, 458-471

\section{Introduction}

In the 21st century, great changes and progress have been observed in science, technology, art, literature in each part of life. These changes and progress have a great influence on education. One of the main objective of education is to train individuals who can keep up with the changes, who have high-level of thinking skills, and who adopt to democratic and universal values (Güneş, 2012; Şahin-Kılıç, 2010). Developed and developing countries remodel their curricula with the purpose of providing critical thinking which is amongst the high-level thinking skills for individuals as well as raising individuals who enjoy democratic values. In Turkey, high level thinking skills and democratic values were integrated into instructional programs implemented in 2005.

Different definitions have been made by different researchers on critical thinking. Critical thinking was defined Paul and Elder (2007:7) "an art of analyzing and assessing thinking in order to improve it"; while Halpern (2013) described critical thinking as "the use of cognitive skills or strategies that increase the likelihood of the desired behaviors". Drennan (2010) stated that critical thinking consists of problem-solving, decision-making, inference, divergent thinking and reasoning. Critical thinking, as understood from the above definitions, is a form of thinking that is experienced in all areas of life (Kökdemir, 2003). One of the foundations of critical thinking is the ability to assess one's own reasoning. What is needed for a successful evaluation is to categorize one's own constant thinking into various elements and test them on the basis of quality standards (Paul \& Elder, 2007).

Nosich (2011) defined that thinking must meet high standards, thus he put forth standards for critical thinking, one of the high-level thinking skills. Nosich (2011) reported that one excludes noncritical thinking thanks to critical thinking standards; hence, critical thinking standards serve as a kind of filter. Also, Nosich (2011) noted that critical thinking standards are prerequisites for logical thinking. At that point, we need to review an idea depending on the critical thinking standards so that we can determine whether it is reasonable or not. Nosich (2011:137) categorized these standards as "clarity, accuracy, significance/relevance, completeness, depth/breadth and precision". Clarity refers to the expression of thought overtly; moreover, the appropriateness of thoughts for real life, the support of thoughts with similar or parallel thinking are expressed in detail.

Accuracy makes sure that all information is correct, logical, reliable and free from an error; in addition, it should be transferred in a correct sequence, reflect the truth and based upon reliable sources. Significance / relevance compels individuals to emphasize crucial facts, respect others, and highlight the main points etc. Completeness means to consider the subject thoroughly with various examples, to provide enough time and proof, to conduct in-depth research. Depth/breadth demands to learn basic and important concepts about a subject as well as taking additional viewpoints into account and have different point of views. Precision implies that ideas are supported with a lot of evidence, thoughts must be certain, the topics should be detailed enough to express the reasons for events.

Democratic individuals are those who are non-prejudiced, tolerant, respectful of differences, who are capable of expressing their thoughts (Cavkaytar, 2013; Demir, 2010). An individual with critical thinking ability has different perspectives, democratic value without prejudice (Aybek, 2010; Facione \& Facione, 1996). In this regard, there is a match between critical thinking and democracy. Today, an important concept that is emphasized by all states is democracy. It is a way of life that values the individuals and gives importance on the integrity of the humans, requires social intelligence and understanding that act together as well as reflecting qualities such as mutual respect, cooperation, tolerance and righteousness (Öncül, 2000: 290). Democracy is fundamental to human understanding and equal treatment (Camkerten, 2001: 17), and It is essential in education. Baran (2010) noted that democratic education "encompasses all activities carried out to transform the most fundamental values of democracy such as respect for human rights, equality, participation, tolerance, cooperation and trust into individual behaviors. Democracy also affects the attitudes of individuals. Democratic attitude is the ensemble of behaviors that individuals carry the basic concepts and values such as opportunity and 
Aybek ve Aslan - Çukurova Üniversitesi Eğitim Fakültesi Dergisi, 46(2), 2017, 458-471

equality of people, freedom and justice into effect as a lifestyle within the framework of boundaries determined by the law (Tekin, Yıldız, Lok \& Taşgın, 2009).

Upon analyzing the relevant literature in Turkey, numerous studies have been conducted to identify the relation between prospective teachers' critical thinking dispositions (Alper, 2010; Can \& Kaymakçı, 2015), their critical thinking and empathic dispositions (Ekinci \& Aybek, 2010), learning styles (Güven \& Kürüm, 2008), educational beliefs (Alkın-Şahin, Tunca \& Ulubey, 2014), democratic attitudes (Özdaş, Ekinci \& Bindak, 2014), and problem-solving skills (Genç \& Kalafat, 2007). When the literature has been examined on this issue in Turkey, no study examines the relation between prospective classroom teachers' critical thinking standards and their democratic attitudes. Critical thinking skills and democratic attitude need to be acquired by the students from primary school years. So that this skill and attitude may be acquired by elementary school students, classroom teachers must possess critical thinking skills and democratic attitude as they will more easily convey these skills, standards and attitudes to the students. Thus, it will be beneficial to determine the relationship between prospective classroom teachers' critical thinking standards and their attitudes towards democracy. This has been observed as a shortcoming by the researchers and the present study has been carried out in this respect. This research is thought to provide a feedback to teacher training programs since the relationship between critical thinking standards and democratic attitudes of classroom teacher candidates has been identified. It is most likely that the research will have a great contribution to the literature.

In service of this goal, the main objective of the research is to analyze the relationship between prospective classroom teachers' critical thinking standards and their attitudes towards democracy. Accordingly, answers for the following questions have been sought:

1. Is there a significant relationship between prospective classroom teachers' critical thinking standards and their attitudes towards democracy?

2. Is there a predictive relationship between prospective classroom teachers' dimensions of critical thinking standards and their attitudes towards democracy?

\section{Method}

\section{Research Design}

The research used relational screening method. Relational models are research models that aim to describe the relationships between variables and analyze the relationships in depth (Karakaya, 2012: 68). Tekbiyık (2014) has reported that relational research method explains the relationship between variables and provides an opportunity to predict the results. Hence, the relational screening model was used in the current study so as to determine the relationship between prospective classroom teachers' critical thinking standards and their attitudes towards democracy.

\section{Population and Sample}

The research was carried out with prospective teachers who study at the Department of Elementary Teaching at Cukurova University and who were selected by the random sampling method. In This method requires the selection of individuals luckily or randomly (Akarsu, 2014). The sample consisted of 326 prospective classroom teachers from the $1^{\text {st }}, 2^{\text {nd }}, 3^{\text {rd }}$ and $4^{\text {th }}$ grades. Among the prospective teachers, 243 were women and 83 were men. The research was carried out in the 20152016 academic year. The data were collected by the researchers. The application of each data collection tool lasted for one hour. Participants voluntarily participated in the research.

\section{Data Collection Tools} Democracy:

The study deployed two data collection tools: Critical Thinking Standards Scale and Attitude Scale for 
Aybek ve Aslan - Çukurova Üniversitesi Eğitim Fakültesi Dergisi, 46(2), 2017, 458-471

Critical Thinking Standards Scale: This research has employed The Critical Thinking Standards Scale (CTSS) developed by Aybek, Aslan, Dinçer and Coskun-Arısoy (2015). Exploratory factor analysis has been primarily conducted. Being a five-point likert type, the tool contains three factors and 42 items. The dimensions- depth, breadth, sufficiency- possess 18 items; precision, accuracy dimensions have 12 items; significance-relevance clarity dimensions contain 12 items. Factor loadings designed to measure each factor consistently range between .35 and .78 . Item correlations range from .07 to .71 . The three dimensions accounted for $35.96 \%$ of the total variance. Cronbach alpha values of the dimensions are as follows: depth, breadth, sufficiency .89, precision, accuracy .78, and significance-relevance clarity .63 . Cronbach's alpha reliability coefficient was found to be 0.75 for the overall scale (Aybek, Aslan, Dinçer \& Coskun-Arısoy, 2015). The lowest score that can be obtained from the scale is 42 while the highest is 210. The tool includes 12 negative expressions which are inverted and calculated. Confirmatory factor analysis was also performed and that the verification of three dimensions was realized.

Attitude Scale for Democracy: This research has also deployed the Attitude Scale for Democracy (DYTO) developed by Oral (2008) in order to measure the attitudes of prospective classroom teachers towards democracy. Being a 5-point Likert type scale, the tool contains 27 items, seven of which are negative. Exploratory factor analysis was conducted during scale development. The scale has 4 factors. The Cronbach Alpha internal consistency coefficient of the tool was determined to be .90. Factor names, sample items and Cronbach Alpha coefficients of the Attitude Scale for Democracy are as regards; Tendency to Democracy ("I want to graduate from a program that is based upon democracy education") .84, Commitment to Democracy ("I cannot think of a life without democracy") .81, Adopt to Democracy Qualities ("Democracy is a form of government that provides rights, freedom and justice") .84 and Negative Overview Towards Democracy ("Democracy is the ruling of aristocracy") .75. Four factors accounted for $63.4 \%$ of the total variance (Oral, 2008). The variance ratio explained by four factors is 63.4\% (Oral, 2008). The lowest score that can be obtained from the scale is 27 while the highest is 135.

After getting the required permission, both scales were used in the study. The Cronbach Alpha coefficients of the scales were reexamined. Cronbach Alpha coefficient of the Critical Thinking Standards scale was determined to be .91 , while that of the scale for democracy was found to be .89 . On this basis, both scales are reliable. (Seçer, 2015).

\section{Data Analysis}

The research data were analyzed through use of the statistical package program. First, the study confirmed whether data provided the general requirements of the parametric tests. Besides, the Kolmogorov-Smirnov test assessed whether the data were distributed normally. As a result of the analyses, the data regarding critical thinking standards (KSZ $=.049, p>.05)$ and attitudes towards democracy (KSZ $=.039, p>.05)$ demonstrated normal distribution. The relation between prospective classroom teachers' critical thinking standards and their attitudes towards democracy was tested through Pearson product-moment correlation. Green and Salkind (2013) stated that normal distribution should be ensured for the correlation analysis, that the data pairs should be randomly selected and that the variables forming the data pairs should be independent of each other. Therefore, this study used Pearson product moment correlation analysis as normal distribution was ensured and continuous variables independent from each other were used. In addition, Multiple Linear Regression Analysis (MLRA) was also used in the study. It has been examined whether some assumptions are met and whether sample number is sufficient for performing MLRA. Pallant (2010) mentioned that there must be at least 40 participants for each predictive variable to be able to perform MLRA. The study includes more than 40 people in each of the dimensions of the Critical Thinking Standards scale. There is no need for multiple linear relationships for MLRA (Field, 2009). A medium level of relationship has been identified between the Critical Thinking Standards and attitude scale towards democracy. It has also been noted that normality must be provided for MLRA and there should be no extreme values (Seçer, 2015). Single variant normality has been achieved in the study. Mahalanobis has examined whether 
Aybek ve Aslan - Çukurova Üniversitesi Eğitim Fakültesi Dergisi, 46(2), 2017, 458-471 multivariate normality assumption is met via distance values (Pallant, 2010). Mahalanobis values were examined and no extreme values were found above the value given.

\section{Findings}

This part presents findings as to whether there is a relation between prospective classroom teachers' critical thinking standards and their attitudes towards democracy, and whether the dimensions of critical thinking standards predict the attitude towards democracy.

Table 1 depicts the match between prospective classroom teachers' critical thinking standards and their attitudes towards democracy.

Table 1.

The distribution of the match between prospective classroom teachers' critical thinking standards and their attitudes towards democracy

\begin{tabular}{lll}
\hline Variables & Critical Thinking Standards & Attitude Towards Democracy \\
\hline Critical Thinking Standards & 1 & - \\
Attitude Towards Democracy & $.598^{*}$ & 1 \\
\hline $\mathrm{N}=326,{ }^{*} \mathrm{p}<.01$ &
\end{tabular}

The Pearson correlation analysis conducted to determine whether there is a significant relation between prospective classroom teachers' critical thinking standards and their attitudes towards democracy (Tuna, 2016) has pointed a positive and medium level of significant relationship $(r=.598, p$ $<.01$ ) between critical thinking standards and attitudes toward democracy. Accordingly, it may be emphasized that prospective teachers' attitude scores towards democracy will increase as their critical thinking standards increase.

Table 2 displays the summary as to whether the dimensions of critical thinking standards such as depth-breadth-sufficiency, precision-accuracy and significance-relevance-clarity predict prospective teachers' attitudes towards democracy.

Table 2.

Multiple linear regression analysis results on how the dimensions of critical thinking standards predict attitude towards democracy

\begin{tabular}{lllllll}
\hline $\begin{array}{l}\text { Predicted } \\
\text { Variables }\end{array}$ & Predicting Variables & $\mathbf{B}$ & $\begin{array}{l}\text { Standard } \\
\text { Error }\end{array}$ & $\boldsymbol{\beta}$ & $\mathbf{t}$ & $\mathbf{p}$ \\
\hline & Stable & 1,015 &, 213 & & 4,770 &, 00 \\
Attitude & Depth-breadth-sufficiency &, 414 &, 062 &, 408 & 6,698 &, 00 \\
$\begin{array}{l}\text { Towards } \\
\text { Democracy }\end{array}$ & Precision-accuracy &, 111 &, 033 &, 160 & 3,392 &, 00 \\
& Significance-relevance-Clarity &, 195 &, 067 &, 172 & 2,899 &, 00 \\
\cline { 2 - 8 } & $\mathbf{R}=, 617 \quad \mathbf{R}^{2}=, 381 \quad \mathbf{F}_{(3-322)}=66,090$ & $\mathbf{p}=, 00$ & & & \\
\hline
\end{tabular}

Multiple linear regression analysis has been conducted to determine how the dimensions of critical thinking standards-depth-breadth-sufficiency-precision-accuracy-significance-relevance-clarity predict prospective teachers' attitudes towards democracy. In this regard, depth-breadth-sufficiency, precision-accuracy and significance-relevance-clarity dimensions were found to have a significant relation with the attitude towards democracy $\left(R=, 617 \quad R^{2}=, 381\right)\left(F_{(3-322)}=66,090 p<, 05\right)$. The three variables account for about $38 \%$ of the attitude towards democracy. With respect to the standardized regression coefficients, the order of significance of the predictive variables related to the attitude 462 
Aybek ve Aslan - Çukurova Üniversitesi Eğitim Fakültesi Dergisi, 46(2), 2017, 458-471

towards democracy are as regards: depth-breadth-sufficiency $(\beta=, 408)$, significance-relevance-clarity $(\beta=, 172)$ and precision-accuracy $(\beta=, 160)$. Taking the significance tests of the regression coefficients into account, all dimensions of critical thinking standards are considered as the significant predictors of attitude towards democracy.

\section{Discussion, Result and Recommendation}

This research has found a positive medium and significant relation between prospective classroom teachers' critical thinking standards and their attitudes towards democracy. It is of great importance for individuals to express their thoughts clearly and freely, and to be conscious of each other. In addition, one of the main objectives of democratic education is to educate individuals who are inquiring, questioning, researching and examining the events depending on their beliefs, who have different perspectives and high-level thinking skills (Özdaş, Ekinci \& Bindak, 2014). Individuals with critical thinking standards should not be prejudiced, they should look at the events with different perspectives, they should be able to explain their thoughts clearly and understandable. Besides, individuals need to possess critical thinking skills in order to become a democratic society. For this reason, it is likely that there is a relationship between critical thinking and democracy. This is supported by the fact that a medium level of positive relationship has been noted between prospective classroom teachers' critical thinking standards and their attitudes towards democracy. One such study conducted by Uluçınar (2012) found a relationship between prospective teachers' critical thinking standards and their democratic values.

This research has also examined how the dimensions of depth-breadth-sufficiency, precisionaccuracy and significance-relevance-clarity predict prospective teachers' attitudes towards democracy. Accordingly, a significant relation has been identified between prospective teachers' critical thinking standards and their attitudes towards democracy. The three dimensions account for approximately $38 \%$ of the attitude towards democracy. The order of significance in terms of the attitudes towards democracy is breadth-width-sufficiency, significance-relevance-clarity and precision-accuracy. Also, width-breadth-sufficiency, significance-relevance-clarity, and precision-accuracy have been determined to significantly predict the attitudes towards democracy. This may reveal the fact that prospective teachers' attitudes towards democracy increase when thoughts are clearly expressed, misunderstanding is free from any possibility, the details are explained if required, when the subject is concrete through examples, supported by visuals, be simple, understandable, accurate, logical and reliable, and when it focuses on the important ones, conveys the thoughts in a comprehensive way, includes the examples as much as the subject, presents sufficient time and evidence, and explains the causes to the finest detail (Ennis \& Norris, 1990; Nosich, 2011; Paul \& Elder, 2007).

Based upon the research findings, the following recommendations are provided:

1. A significant relationship between critical thinking standards and attitudes towards democracy has been determined. The availability of critical thinking and democratic education courses in the education faculties or the provision of critical thinking and democratic value within the other courses based on the subject will ensure that prospective teachers have critical thinking skills, and it will positively influence their attitudes towards democracy.

2. Critical thinking and democracy may be examined via experimental and qualitative researches and different measurement tools.

3. It is most likely to analyze the match between prospective teachers' critical thinking and their attitudes towards democracy with different scales. 
Aybek ve Aslan - Çukurova Üniversitesi Eğitim Fakültesi Dergisi, 46(2), 2017, 458-471

\section{Türkçe Sürümü}

\section{Giriş}

Yirmi birinci yüzyılda bilimde, teknolojide, sanatta, edebiyatta kısaca hayatın her alanında büyük değişmeler ve ilerlemeler meydana gelmiştir. Bu değişmeler ve ilerlemeler eğitimi de etkilemiştir. Günümüzde eğitimin amaçlarından birisi, çağın gerektirdiği değişimlere ayak uydurabilen, üst düzey düşünme becerilerine sahip, demokratik ve evrensel değerleri benimsemiş bireyler yetiştirmektir (Güneş, 2012; Şahin-Kılıç, 2010). Günümüzde üst düzey düşünme becerilerinden bir olan eleştirel düşünme becerisinin bireylere kazandırılması ve demokratik değerlere sahip bireylerin yetiştirilmesi için gelişmiş ve gelişmekte olan ülkeler öğretim programlarında değişiklikler yapmaktadır. Türkiye'de de 2005 yılından itibaren öğretim programlarında değişikliğe gidilmiş, üst düzey düşünme becerilerine ve demokratik değerlere öğretim programlarında yer verilmiştir.

Eleştirel düşünme ile ilgili farklı araştırmacılar tarafından farklı tanımlar yapılmıştır. Paul ve Elder (2007:7) eleştirel düşünmeyi "düşünmeyi geliştirmek amacıyla onu analiz etme ve değerlendirme sanatı olarak" tanımlarken Halpern (2003:13) eleştirel düşünmeyi "istenilen davranışların olabilirliğini arttıran bilişsel beceri ya da stratejilerin kullanılması" olarak tanımlamaktadır. Drennan (2010) eleştirel düşünmenin, problem çözme, karar verme, çıkarımda bulunma, farklı düşünme ve mantık kavramlarından oluştuğunu belirtmiştir. Yukarıdaki tanımlamalardan anlaşıldığı üzere eleştirel düşünme, hayatın tüm alanlarında kullanılan ve hayatın tüm alanlarını etkileyen bir düşünme biçimidir (Kökdemir, 2003). Eleştirel düşünmenin temellerinden birisi, kişinin kendi akıl yürütmesini değerlendirme yeteneğidir. Başarılı bir değerlendirme için gerekli olan, kişinin sürekli olarak düşünmesini çeşitli unsurlara ayırması ve bu unsurları kalite standartları doğrultusunda test etmesidir (Paul \& Elder, 2007).

Nosich (2011) tarafından düşünmenin yüksek standartları karşılanması gerektiği savunulmuş, bu nedenle üst düzey düşünme becerileri içerisinde yer alan eleştirel düşünme ile ilgili standartlar ortaya konulmuştur. Nosich'e (2011) göre, eleştirel düşünme standartları sayesinde birey eleştirel düşünmeyi içermeyen düşünceleri dışarı da bırakmaktadır, yani bu standartlar bir çeşit filtre görevi görmektedir. Ayrıca Nosich'e (2011) göre, eleştirel düşünme standartları mantıklı düşünmenin önkoşuludur. Bu nedenle, bir düşünce eleştirel düşünme standartlarından geçirildikten sonra mantıklı olup olmadığı ortaya konulabilinir. Noisch'e (2011:137) göre bu standartlar "açıklık, doğruluk, önem/alaka, yeterlilik, derinlik/genişlik ve kesinlikten" oluşmaktadır. Illk olarak açıklık standardında, birey düşüncelerini ifade ederken anlamı açıkça belirtmesi, düşüncelerin gerçek hayata uygun olması, düşüncelerin benzer ya da paralel düşüncelerle desteklenmesi, açık ve net olması gerekmektedir.

Doğruluk standardına göre bireyin; düşüncesinin doğru olması, güvenilir kaynaklardan bilgi edinmesi, mevcut bilgileri uygun bir sıra halinde sunması, edindiği bilgileri güvenilir kaynaklara dayandırması gerekmektedir. Önem/alaka standardına göre bireyin; farklı düşüncelere saygılı olması, farklı düşünceleri önemsenmesi, kendisine ait düşünceleri aktarırken düşüncelerin ana noktasını belirginleştirilmesi vb. gerekmektedir. Yeterlilik standardında ise birey; mevcut konu ile ilgili yeterince araştırma yapmalı, mevcut konuyu detaylı bir şekilde düşünülmeli, konu hakkında yeteri kadar örnek vermeli, zaman ve kanıt sunulmalıdır. Derinlik/genişlik standardına göre birey; bir konu hakkında temel ve güçlü kavramları tespit etmeli, belirlenen konuya yönelik farklı seçenekler sunmalı, konuya farklı bakış açılarıyla bakmalıdır. Kesinlik standardında ise birey; düşüncelerini ifade ederken kanıtlarla desteklemeli, düşüncelerinde kesinlik olmalı, mevcut konuyu detaylı bir şekilde ele almalı, konunun nedenlerini kesin bir şekilde açıklamalıdır.

Demokratik bireyler; olaylara farklı açılardan bakabilen, ön yargılı olmayan, hoşgörülü, farklılıklara saygılı, düşüncelerini ifade edebilen bireylerdir (Cavkaytar, 2013; Demir, 2010). Eleştirel düşünme becerisine sahip bir bireyde olaylara farklı açıdan bakar, ön yargısızdır, hoşgörülüdür, demokratik değerle sahiptir (Aybek, 2010; Facione \& Facione, 1996). Bu bakımdan, eleştirel düşünme ile demokrasi arasında bir ilişkiden söz edilebilir. Günümüzde tüm devletlerin üzerinde durduğu önemli bir kavramda 464 
Aybek ve Aslan - Çukurova Üniversitesi Eğitim Fakültesi Dergisi, 46(2), 2017, 458-471

demokrasidir. Öncül'e (2000: 290) göre demokrasi "bireye değer veren ve insan kişiliğinin bütünlügünü önemli sayan, birlikte davranan insan zekâ ve anlayışına ihtiyaç duyan ve karşılıklı saygı, işbirliği, hoşgörü ve doğruluk gibi nitelikleri yansıtan, toplumsal ilişkilere yer veren bir yaşam yoludur." Çamkerten (2001: 17) ise demokrasiyi "Insana saygı ve eşit muamele anlayışı üzerinde esas anlamını bulma" şeklinde tanımlamıştır. Demokrasi kavramı eğitim alanında önemli bir yere sahiptir. Baran (2010) tarafından demokrasi eğitiminin "insan haklarına saygı, eşitlik, katılım, hoşgörü, işbirliği, güven gibi demokrasinin en temel değerlerini, bireylerin davranışlarına dönüştürmek için yürütülen tüm faaliyetleri kapsadığı" belirtilmiștir. Demokrasi kavramı bireylerin tutumlarını da etkilemektedir. Demokratik tutum "Bireylerin fırsat ve imkan eşitliği, özgürlük ve adalet gibi temel kavram ve değerleri yasalarla belirlenen sınırlar çerçevesinde bir yaşam tarzı olarak hayata geçirdiği davranışlar bütünüdür." (Tekin, Yıldız, Lök \& Taş̧̆ın, 2009: 205-206).

Türkiye'de alanyazın incelendiğinde, öğretmen adaylarının eleştirel düşünme eğilimlerini (Alper, 2010; Can \& Kaymakçı, 2015), eleştirel düşünme eğilimleri ile empatik eğilimlerini (Ekinci \& Aybek, 2010), öğrenme stillerini (Güven \& Kürüm, 2008), eğitim inançları (Alkın-Şahin, Tunca \& Ulubey, 2014), demokratik tutumlarını (Gömleksiz \& Çetintaş, 2011), demokrasiye ilişkin tutumlarını (Özdaş, Ekinci \& Bindak, 2014), demokratik tutumları ile problem çözme becerisi arasındaki ilişkiyi (Genç \& Kalafat, 2007) inceleyen araştırmalara rastlanılmışır. Alanyazında sınıf öğretmeni adaylarının eleştirel düşünme standartları ile demokratik tutumları arasındaki ilişkiyi inceleyen herhangi bir çalışmaya rastlanılmamıştır. Bu durum araştırmacılar tarafından bir eksiklik olarak değerlendirilmiş ve bu çalışmanın yapılmasına karar verilmiştir. Eleştirel düşünme becerisinin ve demokratik tutumun daha ilkokul yıllarından itibaren öğrencilere kazandırılması gerekmektedir. Bu becerinin ve tutumun ilkokul öğrencilerine kazandırılması için sınıf öğretmenlerinin eleştirel düşünme becerisi ile standartlarına ve demokratik tutuma sahip olmalıdır. Çünkü sınıf öğretmeni eleştirel düşünme becerisi ile standartlarına ve demokratik tutuma sahip olması durumunda bu beceriyi, standartları ve tutumu öğrencilere daha kolay aktaracaktır. Bu çalışma ile sınıf öğretmeni adaylarının eleştirel düşünme standartları ile demokratik tutumları arasındaki ilişki ortaya konulacağından, öğretmen yetiştirme programlarına da bir dönüt sağlayacağı düşünülmektedir. Yapılan bu araştırmanın alanyazına katkı sağlayacağı umulmaktadır.

Bu çalışmanın amacı, sınıf öğretmeni adaylarının eleştirel düşünme standartları ile demokrasiye yönelik tutumları arasındaki ilişkiyi incelemektir. Araştırma kapsamında aşağıdaki sorulara yanıt aranmıştır:

1. Öğretmen adaylarının eleştirel düşünme standartları ile demokrasiye yönelik tutumları arasında anlamlı bir ilişki var mıdır?

2. Öğretmen adaylarının eleştirel düşünme standartlarının alt boyutları ile demokrasiye yönelik tutumları arasında yordayıcı bir ilişki var mıdır?

\section{Yöntem}

\section{Araştırmanın Modeli}

Araştırmada, tarama modellerinden biri olan ilişkisel tarama modeli kullanılmıştır. Karakaya (2012: 68) ilişkisel taramayı "iki veya daha fazla değişken arasındaki ilişkileri betimlemek amacıyla yürütülen ve ilişkilerin derinlemesine analiz edildiği araştırmalar" şeklinde tanımlamıştır. Tekbıyık (2014) ilişkisel araştırma yönteminin, değişkenler arasındaki ilişkileri açıklama ve sonuçları tahmin etme fırsatı sunduğunu belirtmiştir. Bu araştırmada da, öğretmen adaylarının eleştirel düşünme standartları ile demokrasiye yönelik tutumları arasındaki ilişki incelendiğinden ilişkisel tarama modeli kullanılmışır.

\section{Evren ve Örneklem}

Araştırmanın evrenini Çukurova Üniversitesi'nde Sınıf Öğretmenliği ABD'de öğrenim gören öğretmen adayları oluşturmaktadır. Araştırmada rassal örnekleme yöntemi kullanılmıştır. Bu yöntemde, bireyler topluluğundan seçim şansla veya gelişigüzel gerçekleştirilir (Akarsu, 2014). Yapılan bu araştırmada da, öğretmen adayları gelişigüzel belirlenmiştir. Araştırmaya 1, 2, 3 ve 4. sınıflarda öğrenim 
Aybek ve Aslan - Çukurova Üniversitesi Eğitim Fakültesi Dergisi, 46(2), 2017, 458-471

gören 326 sınıf öğretmeni adayı katılmıştır. Öğretmen adaylarııı 243'ü kadın, 83'ü erkektir. Araştırma, 2015-2016 eğitim-öğretim yılında gerçekleştirilmiştir. Araştırmanın verileri bizzat araştırmacılar tarafından toplanmıştır. Veri toplama araçlarının uygulanması yaklaşık olarak bir ders saati sürmüştür. Katılımcılar gönüllük esasına dayalı olarak araştırmaya katılmışlardır.

\section{Veri Toplama Araçları}

Araştırmada iki tür veri toplama aracı kullanılmıştır. Bunlar:

Eleştirel Düşünme Standartları Ölçeği: Araştırmada Aybek, Aslan, Dinçer ve Coşkun-Arısoy (2015) tarafından geliştirilen Eleştirel Düşünme Standartları Ölçeği (EDSÖ) kullanılmıştır. Ölçek geliştirilirken öncelikle açımlayıcı faktör analizi yapıımışır. Yapılan açımlayııı faktör analizi sonucunda ölçeğin üç faktörden ve 42 maddeden olştuğu tespit edilmiştir. Derinlik-genişlik- yeterlilik alt boyutu 18 maddeden, kesinlik-doğruluk alt boyutu 12 maddeden ve önem-alaka-açıklık alt boyutu 12 madden oluşmaktadır. Ölçeğe ait maddelerin faktör yükleri .35 ile .78 arasında değişmektedir. Madde korelasyonları ise .07 ile .71 arasında değişmektedir. Üç boyut toplam varyansın \%35.96'sını açıklamaktadır. Ölçeğin Cronbach Alpha katsayısı da incelenmiştir. Derinlik-genişlik- yeterlilik alt boyutunun Cronbach Alpha katsayısı .89, kesinlik-doğruluk alt boyutunun Cronbach Alpha katsayısı .78, önem-alaka-açıklık alt boyutunun Cronbach Alpha katsayısı .63 ve toplam Cronbach Alpha katsayısı .75 bulunmuştur (Aybek, Aslan, Dinçer \& Coşkun-Arısoy, 2015). Ölçekten alınabilecek en düşük puan 42 iken en yüksek puan 210'dur. Ölçekte 12 olumsuz ifade bulunmaktadır ve bu ifadeler ters çevrilip hesaplanmaktadır. Ölçek $5^{\prime}$ li likert şeklinde düzenlenmiştir. Ölçeğin doğrulayıcı faktör analizi de yapılmış ve ölçeğin üç alt boyuttan oluştuğu doğrulanmıştır.

Demokrasiye Yönelik Tutum Ölçeği: Araştırmada sınıf öğretmeni adaylarının demokrasiye yönelik tutumlarını ölçmek amacıyla Oral (2008) tarafından geliştirilen "Demokrasiye Yönelik Tutum Ölçeği (DYTÖ)" kullanılmışır. Ölçek 5'li likert tipi şeklinde hazırlanmış ve 7'si olumsuz olmak üzere toplam 27 maddeden oluşmaktadır. Ölçek, geliştirilirken açımlayııı faktör analizi uygulanmıştır. Yapılan analiz sonucunda ölçeğin dört faktör altında toplandığı tespit edilmiştir. Ölçeğin dört faktör altında toplandığı ve açıklanan varyansın \%63.4 olduğu tespit edilmiştir. Ölçeğe ait demokrasiye eğilim alt boyutuna "Demokrasi eğitiminin ağırıklı olduğu bir programdan mezun olmak isterim", demokrasiye bağlılık alt boyutuna "Demokrasinin olmadığı bir yaşam düşünemiyorum", demokrasi niteliklerini benimseme alt boyutuna "Demokrasi hak, özgürlük ve adaleti sağlayan bir yönetim biçimidir" ve demokrasiye Olumsuz bakış alt boyutuna "Demokrasi elit tabakanın yönetimidir" maddeleri örnek verilebilir (Oral, 2008). Ölçekten alınabilecek en yüksek puan 135 iken en düşük puan 27'dir. Ölçeğin genelinin Cronbach Alpha iç tutarlıık katsayısının .90 , demokrasiye eğilim alt faktörünün .84 , demokrasiye bağılıık alt boyutunun .81 , demokrasi niteliklerini benimseme alt boyutunun .84 ve demokrasiye olumsuz bakış alt boyutunun .75 olduğu tespit edilmiştir.

Gerekli izin alındıktan sonra her iki ölçekte bu araştırmada kullanılmışıı. Bu araştırmada ölçeklerin Cronbach Alpha katsayıları tekrar incelenmiştir. Yapılan analiz sonucunda eleştirel düşünme standartları ölçeğinin Cronbach Alpha katsayısı .91 bulunurken, demokrasiye yönelik tutuma ait ölçeğin Cronbach Alpha katsayısı .89 bulunmuştur. Bu sonuca dayalı olarak her iki ölçeğinde oldukça güvenilir olduğu söylenebilir (Seçer, 2015).

\section{Verilerin Analizi}

Araştırmanın verileri, istatistik paket programı kullanılarak analiz edilmiştir. Önce, verilerin parametrik testlerin genel koşullarını sağlayıp sağlamadığı kontrol edilmiştir. Verilerin normal dağılım gösterip göstermediğine Kolmogorov Smirnov testi ile bakılmıştır. Kolmogorov Smirnov testinde eleştirel düşünme standartları (KSZ=.049, p>.05) ve demokrasiye yönelik tutum (KSZ=.039, p>.05) ölçeklerinin normal dağılım gösterdiği tespit edilmiştir. Araştırmada öğretmen adaylarının eleştirel düşünme standartları ile demokrasiye yönelik tutum ölçekleri arasındaki ilişkiyi saptayabilmek için Pearson Çarpım Momentler Korelasyon analizi kullanılmıştır. Green ve Salkind (2013) korelasyon analizini uygulanması için normal dağıımın olması gerektiğini, veri çiftlerinin evrende yansız atamayla seçilmiş ve veri çiftlerini 
Aybek ve Aslan - Çukurova Üniversitesi Eğitim Fakültesi Dergisi, 46(2), 2017, 458-471

oluşturan değişkenlerin birbirinden bağımsız olmaları gerektiğini belirtmişlerdir. Bu araştırmada da, normal dağııım sağlandığından ve birbirinden bağımsız sürekli değişkenler kullanıldığından pearson çarpım momentler korelasyon analizi kullanılmıştır. Ayrıca araştırmada Çoklu Doğrusal Regresyon Analizi (ÇDRA) kullanıımıştır. ÇDRA yapabilmek için bazı varsayımların karşılanıp karşılanmadığına bakılmıştır. ÇDRA yapabilmek için örneklemin yeterli sayıda olması gerekmektedir. Pallant (2010) ÇDRA yapabilmek için her bir yordayan değişken için en az 40 katııımının olması gerektiğini belirtmiştir. Araştırmada eleştirel düşünme standartları ölçeğine ait boyutların her biri için 40 'tan fazla kişinin olduğu belirlenmiştir. ÇDRA için çoklu doğrusal bağıntının olmaması gerekmektedir (Field, 2009). Bu araştırmada, eleştirel düşünme standartları ölçeği ile demokrasiye yönelik tutum ölçeği arasında orta düzeyde bir ilişkinin olduğu tespit edilmiştir. ÇDRA yapabilmek için normalliğin sağlanması ve uç değerlerin olmaması gerektiği belirtilmektedir (Seçer, 2015). Araştırmada tek değişkenli normalliğin sağlandığı yukarıda belirtilmiştir. Çok değişkenli normallik varsayımının karşılanıp karşılanmadığı Mahalanobis uzaklık değerleri yardımıyla incelenmiştir (Pallant, 2010). Bu araştırmada, mahalanobis değerleri incelenmiş ve verilen değerin üstünde uç değere rastlanılmamıştır.

\section{Bulgular}

Bu bölümde sınıf öğretmeni adaylarının; eleştirel düşünme standartları ile demokrasiye yönelik tutum arasında anlamlı bir ilişkinin olup olmadığına ve eleştirel düşünme standartlarına ait boyutların demokrasiye yönelik tutumu yordayıp yordamadığına ilişkin bulgular yer almaktadır.

Öğretmen adaylarının eleştirel düşünme standartları ile demokrasiye yönelik tutumları arasındaki ilişki incelenip Tablo 1'de sunulmuştur.

Tablo 1.

Öğretmen adaylarının eleştirel düşünme standartları ile demokrasiye yönelik tutumları arasındaki ilişkinin dağılımı

\begin{tabular}{l|c|c}
\hline \multicolumn{1}{c|}{ Değişkenler } & $\begin{array}{c}\text { Eleştirel Düşünme } \\
\text { Standartları }\end{array}$ & $\begin{array}{c}\text { Demokrasiye Yönelik } \\
\text { Tutum }\end{array}$ \\
\hline Eleştirel Düşünme Standartları & 1 & - \\
Demokrasiye Yönelik Tutum & $.598^{*}$ & 1 \\
\hline
\end{tabular}

$\mathrm{N}=326,{ }^{*} \mathrm{p}<.01$

Öğretmen adaylarının eleştirel düşünme standartları ile demokrasiye yönelik tutumları arasında anlamlı bir iliş̧i olup olmadığını belirlemek için yapılan pearson korelasyon analizi sonucunda; eleştirel düşünme standartları ile demokrasiye yönelik tutumları arasında pozitif yönlü orta düzeyde (Tuna, 2016) anlamlı bir ilişki $(r=.598, p<.01)$ olduğu tespit edilmiştir. Buna göre, öğretmen adaylarının eleştirel düşünme standartları puanlarının artması durumunda demokrasiye yönelik tutum puanlarııın da artacağı söylenebilir.

Öğretmen adaylarının eleştirel düşünme standartları ölçeğine ait derinlik-genişlik-yeterlilik, kesinlik-doğruluk ve önem-alaka-açıklık alt boyutlarının demokrasiye yönelik tutumlarını yordayıp yordamadığı incelenmiş ve sonuçlar Tablo 2'de sunulmuştur. 
Aybek ve Aslan - Çukurova Üniversitesi Eğitim Fakültesi Dergisi, 46(2), 2017, 458-471

Tablo 2.

Eleştirel düşünme standartlarına ait alt boyutların demokrasiye yönelik tutumu yordamasına ilişkin çoklu doğrusal regresyon analizi sonuçları

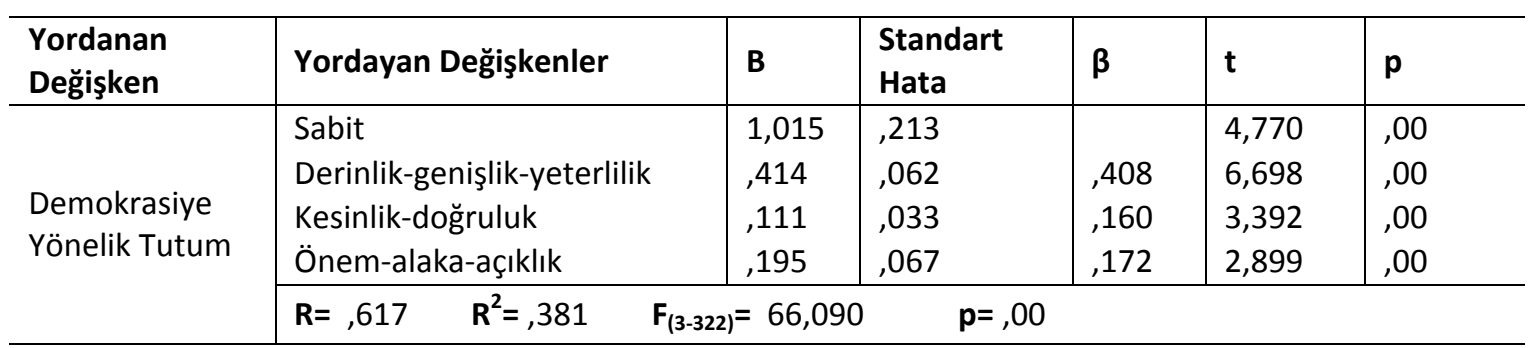

Öğretmen adaylarının demokrasiye yönelik tutumları, eleştirel düşünme standartları ölçeğine ait alt boyutlarının ne şekilde yordadığını ortaya koymaya yönelik olarak yapılan çoklu doğrusal regresyon analizi sonucunda derinlik-genişlik-yeterlilik, kesinlik-doğruluk ve önem-alaka-açıklık değişkenleri birlikte demokrasiye yönelik tutumları ile anlamlı bir ilişki $(R=, 617 \quad R 2=, 381)$ sergilemişlerdir $(F(3-322)=66,090$ $p<, 05)$. Söz konusu üç değişken birlikte, demokrasiye yönelik tutumun yaklaşık \%38'ini açıklamaktadır. Standartlaştırılmış regresyon katsayılarına göre yordayıcı değişkenlerin, demokrasiye yönelik tutum üzerindeki önem sırası derinlik-genişlik-yeterlilik $(\beta=, 408)$, önem-alaka-açıklık $(\beta=, 172)$ ve kesinlikdoğruluktur $(\beta=, 160)$. Regresyon katsayılarının anlamlılık testleri göz önüne alındığında, yordayıcı değişkenlerde derinlik-genişlik-yeterlilik, kesinlik-doğruluk ve önem-alaka-açıklık değişkenlerinin demokrasiye yönelik tutum üzerinde anlamlı yordayıcı olduğu görülmektedir.

\section{Tartışma, Sonuç ve Öneriler}

Öğretmen adaylarının eleştirel düşünme standartları ile demokrasiye yönelik tutumları arasında pozitif yönlü orta düzeyde anlamlı bir ilişkinin olduğu bulunmuştur. Demokraside, bireylerin düşüncelerini açık bir şekilde ifade etmeleri, özgürce düşüncelerini aktarabilmeleri, birbirlerine karşı anlayışı olmaları önemlidir. Ayrıca demokratik eğitimin amaçlarından birisi de soran, sorgulayan, çevresindeki olayları kanıta dayalı olarak araştırıp inceleyebilen, olaylara farklı bakış açılarıyla bakabilen, üst düzey düşünme becerilerine sahip bireyler yetiştirmektir (Özdaş, Ekinci \& Bindak, 2014). Eleştirel düşünme standartlarına sahip bireyler; önyargıları olmamalı, olaylara farklı bakış açılarıyla bakabilmeli, düşüncelerini açık ve anlaşıır bir şekilde açıklayabilmelidirler. Ayrıca demokratik bir toplum olabilmek için bireylerin eleştirel düşünme becerilerine sahip olmaları gerekmektedir. Bu nedenle, eleştirel düşünme ile demokrasi arasında bir ilişkinin olduğu söylenebilir. Öğretmen adaylarının eleştirel düşünme standartları ile demokrasiye yönelik tutumları arasında pozitif yönde orta düzeyde bir ilişkinin çıkması bu durumu destekler niteliktedir. Uluçınar (2012) tarafından yapılan araştırmada da, öğretmen adaylarının eleştirel düşünme eğilimleri ile demokratik değerleri arasında ilişki bulunmuştur. Bu sonuç da, yapılan bu araştırmanın sonucunu destekler niteliktedir.

Öğretmen adaylarının demokrasiye yönelik tutumları üzerinde, eleştirel düşünme standartları ölçeğine ait alt boyutların ne şekilde yordadığı incelenmiştir. Araştırma sonucunda eleştirel düşünme standartları ölçeğinin alt boyutlarının birlikte demokrasiye yönelik tutum ile anlamlı bir ilişki sergiledikleri tespit edilmiştir. Söz konusu üç boyut birlikte, demokrasiye yönelik tutumun yaklaşık \%38'ini açıklamaktadır. Araştırma sonucunda yordayıcı değişkenlerin, demokrasiye yönelik tutum üzerindeki önem sırası derinlik-genişlik-yeterlilik, önem-alaka-açıklık ve kesinlik-doğruluktur. Ayrıca araştırma sonucunda, derinlik-genişlik-yeterlilik, önem-alaka-açıklık ve kesinlik-doğruluk değişkenlerinin demokrasiye yönelik tutum üzerinde anlamlı yordayıcı olduğu görülmüştür. Bu sonuçtan yola çıkarak öğretmen adaylarının; bir konu hakkındaki düşüncelerini açık bir şekilde söylemeleri, düşüncelerinin yanlış anlaşılma ihtimalinin olmaması, gerektiğinde ayrıntıya girerek düşüncelerini ifade etmesi, konu hakkında düşüncelerini örnek vererek somut hale getirmesi, düşüncelerini aktarırken çeşitli görsellerle desteklemesi, sade ve anlaşılır bir şekilde düşüncelerini ifade etmesi, düşüncesinin doğru ve mantıklı 
Aybek ve Aslan - Çukurova Üniversitesi Eğitim Fakültesi Dergisi, 46(2), 2017, 458-471

olması, verilen bilgilerin güvenilir olması, bilginin doğru bir sıra halinde verilmesi, düşüncelerini karşııındakine aktarırken önemli gördüğü noktaları vurgulaması, önemli konuların üzerine odaklanması, konuşulan konular arasında bağ kurulması, düşüncelerin detaylı bir şekilde aktarılması, üzerinde konuşulan konu ile ilgili yeteri kadar örnek verilmesi, konuya yeteri kadar zaman ayrılması ve konuyla ilgili olarak yeterince kanıt sunulması, konun nedenlerinin en ince ayrıntısına kadar açıklanması, konuyla ilgili derinlemesine bilgi verilmesi, konuya farklı bakış açılarıyla bakılmasının (Ennis \& Norris, 1990; Nosich, 2011; Paul \& Elder, 2007) demokrasiye yönelik tutumlarını arttırdığı söylenebilir.

Araştırma sonucuna dayalı olarak aşağıdaki öneriler geliştirilmiştir:

1. Araştırma sonucunda eleştirel düşünme standartları ile demokrasiye yönelik tutum arasında bir ilişki çıkmıştır. Bu nedenle, eğitim fakültelerinde eleştirel düşünme ve demokratik eğitim ile ilgili derslerin olması ya da eleştirel düşünmenin ve demokrasi değerinin konu temelli olarak diğer derslerin içerisinde verilmesi, öğretmen adaylarının eleştirel düşünme becerisine sahip olmalarını sağlayacak ve demokrasiye yönelik tutumlarını olumlu yönde etkileyecektir.

2. Eleştirel düşünme ve demokrasi ile ilgili deneysel ve nitel araştırmaların ve farklı veri toplama araçlarının kullanılarak araştırmalar yapılması alanyazına katkı sağlayacaktır.

3. Öğretmen adaylarııı eleştirel düşünme ile demokrasiye yönelik tutumlarının farklı ölçeklerle ilişkisi incelenebilir. 
Aybek ve Aslan - Çukurova Üniversitesi Eğitim Fakültesi Dergisi, 46(2), 2017, 458-471

\section{References}

Akarsu, B. (2014). Hipotezlerin, değişkenlerin ve örneklemin belirlenmesi. M. Metin (Edt.) Kuramdan uygulamaya eğitimde bilimsel araştırma yöntemleri. (ss, 21-43 içinde) Ankara: Pegem Akademi. (1. Baskı)

Alkın-Şahin, S., Tunca, N., \& Ulubey, Ö. (2014). Öğretmen adaylarının eğitim inançları ile eleştirel düşünme eğilimleri arasındaki ilişki. ilköğretim Online, 13(4), 1473-1492.

Alper, A. (2010). Critical thinking disposition of pre-service teachers. Eğitim ve Bilim, 35(158), 14-27.

Aybek, B. (2010). Örneklerle düşünme ve eleştirel düşünme. Adana: Nobel Kitapevi. (1. Baskı)

Aybek, B., Aslan, S., Dinçer, S. ve Coşkun-Arısoy, B. (2015). Öğretmen adaylarına yönelik eleştirel düşünme standartları ölçeği: Geçerlik ve güvenirlik çalışması. Kuram ve Uygulamada Eğitim Yönetimi, 21(1), 25-50.

Baran, S. (2010). IIlköğretim 6. ve 7. sınıf öğrencilerinin demokratik tutum geliştirmesinde aile, öğretmen ve okul yönetimini algılama biçimleri. Yayımlanmamış yüksek lisans tezi. Uludağ Üniversitesi, Bursa.

Can, Ş., \& Kaymakçı, G. (2015). Öğretmen adaylarının eleştirel düşünme eğilimleri. E-Journal of New World Sciences Academy, 10(2), 68-83.

Çamkerten, F. (2001). Okul öncesi eğitimde uygulanan program ve çocukların demokratik davranışları ile öğretmenlerin demokratik tutum ve davranışları arasındaki ilişkinin değerlendirilmesi. Yayımlanmamış yüksek lisans tezi. Ankara Üniversitesi, Ankara.

Cavkaytar, S. (2013). Sınıf öğretmeni adaylarının Türkçe dersinde demokratik kültür bilincini geliştirmeye ilişkin görüşleri. Turkish Studies, 8(13), 607-631.

Demir, M.K. (2010). Dört yıl arayla ilköğretim beşinci sınıf öğrencilerinin sınıf öğretmenlerinin demokratik davranışlar sergileme sıklığına ilişkin görüşleri. Türk Eğitim Bilimleri Dergisi, 8(1), 2140 .

Drennan, J. (2010). Critical thinking as an outcome of master's degree in nursing programme. Journal of Advanced Nursing, 66(2), 422-431.

Ekinci, Ö., \& Aybek, B. (2010). Öğretmen adaylarının empatik ve eleştirel düşünme eğilimlerinin incelenmesi. Illöğretim Online, 9(2), 816-827.

Ennis, R.H., \& Norris, S.P. (1990). Critical thinking assessment: status, issues, needs. In Algina, J. \& Leggs, S. (Eds.), Cognitive assessment of language and math outcomes (pp. 1-42). Norwood, N.J.: Ablex Publishing. (1 $1^{\text {st }}$ Press)

Facione, N.C., \& Facione, P.A. (1996). Externalizing the critical thinking in knowledge development and clinical judgment. Nursing Outlook, 44, 129-136.

Field, A. (2009). Discovering statics using SPSS. London: SAGE. ( $3^{\text {th }}$ Press)

Genç, S.Z., \& Kalafat, T. (2007). Öğretmen adaylarının demokratik tutumları ile problem çözme becerilerinin çeşitli değişkenler açısından incelenmesi. Pamukkale Üniversitesi Eğitim Fakültesi Dergisi, 2(22), 10-22.

Gömleksiz, M.N., \& Çetintaş, S. (2011). Öğretmen adaylarının demokratik tutumları (Fırat, Dicle,7 Aralık, Cumhuriyet ve Erzincan Üniversiteleri Örneği). Dicle Üniversitesi Ziya Gökalp Eğitim Fakültesi Dergisi, 17, 1-14.

Green, S.B., \& Salkind, N.J. (2013). Using spss for windows and macintosh: analyzing and understanding data. New Jersey: Pearson. ( $7^{\text {th }}$ Press) 
Aybek ve Aslan - Çukurova Üniversitesi Eğitim Fakültesi Dergisi, 46(2), 2017, 458-471

Güneş, F. (2010). Öğrencilerin düşünme becerilerini geliştirme. Türklük Bilimi Araştırmaları, 32, 127-146.

Güven, M., \& Kürüm, D. (2008). Öğretmen adaylarının öğrenme stilleri ile eleştirel düşünme eğilimleri arasındaki ilişki (Anadolu Üniversitesi eğitim fakültesi öğrencileri üzerinde bir araştırma). ilköğretim Online, 7(1), 53-70.

Halpern, D.F. (2013). Thought knowledge: An introduction to critical thinking. London: Lawrence Erlbaum Associates. ( $5^{\text {th }}$ Press)

Karakaya, ì. (2012). Bilimsel araştırma yöntemleri. A. Tanrıöğen (Edt.) Bilimsel araştırma yöntemleri. (ss, 57-83 içinde). Ankara: Anı Yayıncılık. (2. Baskı)

Kökdemir, D. (2003). Belirsizlik durumlarında karar verme ve problem çözme. Yayımlanmamış doktora tezi. Ankara Üniversitesi, Ankara.

Nosich, G.M. (2011). Learning to think things through: a guide to critical thinking across the curriculum. New Jersey: Prentice-Hall. (4 ${ }^{\text {th }}$ Press)

Oral, B. (2008). The evaluation of the student teachers' attitudes toward Internet and democracy. Computers \& Education, 50(1), 437-445.

Öncül, R. (2000). Eğitim ve eğitim bilimleri sözlüğü. İstanbul: Milli Eğitim Bakanlığı Yayınları. (1. Baskı)

Özdaş, F., Ekinci, A., \& Bindak, R. (2014). Öğretmenlerin demokrasiye ilişkin tutumlarının bazı değişkenler açısından incelenmesi. Inönü Üniversitesi Eğitim Fakültesi Dergisi, 15(3), 65-81.

Pallant, J. (2010). Spss survival manual: a step by step guide to data analysis using spss for windows. Australia: Australian Copyright. (4 ${ }^{\text {th }}$ Press)

Paul, R., \& Elder L. (2007). The miniature guide to critical thinking: Conceptsand tools. Foundation for Critical Thinking Press. http://www.petersj.people.cofc.edu/Courselnformation/ MiniCriticalThinking.pdf Erişim Tarihi: 20.10.2015

Seçer, i. (2015). SPSS ve Lisrel ile pratik veri analizi: analiz ve raporlaştırma. Ankara: Anı Yayıncılık. (2. Baskı)

Şahin-Kılıç, H. (2010). Ilköğretim okullarında sosyal bilgiler dersini yürüten 4. ve 5. sınıf öğretmenlerinin sosyal bilgiler dersi öğretim programında yer alan değerlerin kazandırılmasına ilişkin görüşleri. Yayımlanmamış yüksek lisans tezi. Gazi Üniversitesi, Ankara.

Tekbıyık, A. (2014). İlişkisel araştırma yöntemi. M. Metin (Edt.) Kuramdan uygulamaya eğitimde bilimsel araştırma yöntemleri. (ss, 99-114 içinde) Ankara: Pegem Yayıncılık. (1. Baskı)

Tekin, M., Yıldız, M., Lök, S., \& Taşğın, Ö. (2009). Beden eğitimi ve spor yüksekokulunda öğrenim gören öğretmen adaylarının çeşitli değişkenlere göre demokratik tutum düzeylerinin incelenmesi. Niğde Üniversitesi Beden Eğitimi ve Spor Bilimleri Dergisi, 3 (3), 204-212.

Tuna, F. (2016). Sosyal bilimler için istatistik. Ankara: Pegem Yayıncılık. (1. Baskı)

Uluçınar, U. (2012). Öğretmen adaylarının eleştirel düşünme eğilimlerinin demokratik değerleri yordama düzeyi. Yayımlanmamış yüksek lisans tezi. Eskişehir Osman Gazi Üniversitesi, Eskişehir. 